\section{Indigenous Dress} Theory and Dress in Canadian Residential Schools

By Shawkay Ottmann

\section{Abstract}

Indian Residential Schools were apart of Canada's aggressive assimilative policy for Indigenous peoples (First Nations, Métis, Inuit), demonstrating the attempts to erase Indigenous people as a cultural and political entity. Ultimately, the schools were key to the "cultural genocide" that occurred. ${ }^{1}$ Upon arriving at the schools, Indigenous children would be stripped of their clothes, which was quickly replaced with foreign dress. The act of forcibly taking away and replacing the clothing of the children entering Indian Residential Schools is a direct result of the assimilative policy. This paper outlines Western dress and uniform theory. From there, an Indigenous dress theory is proposed based on Indigenous epistemologies, which emphasizes the differentiation between Western and Indigenous worldviews. Indian Residential School history is shared before examining the use of dress in the schools. Finally, Western and Indigenous dress theories are used in tandem to analyze the events and effects of stripping Indigenous children of their clothes. Understanding the individual experience is possible due to the voices of school Survivors who shared their stories with the TRC and The Legacy of Hope Foundation, those who wrote their own words down, and the voices found in the archival record.

\title{
KEYWORDS:
}

CULTURAL GENOCIDE

IDENTITY

ASSIMILATION

CIVILIZATION

UNIFORMS

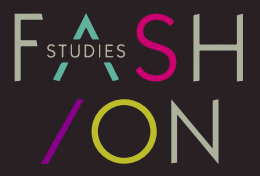


Indian Residential Schools were a part of Canada's hostile assimilative policy for Indigenous peoples (First Nations, Métis, Inuit), demonstrating the continuous attempts to erase Indigenous peoples as a cultural, and political entity in the nineteenth and twentieth centuries. Ultimately, the schools were key to the "cultural genocide" that occurred. ${ }^{2}$ In the Indian Residential Schools, dress was aggressively changed to fit with Western ideals of civilization. Indeed, it was a crucial component in attempting to fulfill the Indian Residential Schools' purpose. As dress is an embodied object, it reflects identity. The Indigenous epistemology embedded in how dress was created, worn, and cared for was often violently removed and replaced with European-styled school uniforms in an attempted reorientation to European standards. These attempts were ultimately failures as how the dress was implemented, the condition and care of the clothes, and the punishment enacted were all contrary to achieving assimilation. Rather, students were taught body shame and were reminded of their position at the bottom of Canadian society's hierarchy. While other elements contributed to trauma and the cultural genocide perpetuated in residential schools, dress is an important factor because clothing is the first object a body interacts with.

This paper will outline Western dress and uniform theory. From there, an Indigenous dress theory is proposed based on Indigenous epistemologies, which emphasizes the differentiation between Western and Indigenous worldviews. Indian Residential School history is shared before examining the use of dress in the schools. Finally, Western and Indigenous dress theories are used in tandem to analyze the events and effects of stripping Indigenous children of their clothes. 


\section{To understand the implications and effect of Indian Residential School uniforms on the children required to wear them, an un- derstanding of both the body and dress must be realized.}

As the site of wear, the body is a primary influencer of dress and therefore vitally important to understanding how dress functions. Joanne Entwistle's embodiment theory places the mind in the body, describing "body as environment of the self," as it is the medium through which people perceive the world. "Body as environment of the self" is a description of embodiment that depicts a dynamic relationship where the mind is firmly rooted in the body, and the body in the world. Further, the body and dress are intertwined, dress acting as a border between the self and society. Dress itself does not simply include clothing, but is the complete system of worn adornment. ${ }^{4}$ Like the mind, dress is also embodied, meaning it can be viewed as an extension of personhood and identity. Annette Lynch and Mitchell D. Strauss note that dress "becomes part of who we think we are" and that this starts at a very young age. ${ }^{5}$ Culture and society then, are a part of the environment of "the self" but not the only influence, in that identity also resides in the body of an individual. Dress is a system in which differing influences converge.

Various forms of dress allow for a system of signals to be transmitted to others without the necessity of body language or words, making it key in first impressions and social interaction. The signals transmitted can present a number of different aspects of identity. ${ }^{6}$ This impact is reciprocal. While culture and identity are displayed through dress, clothing also has an impact on those who wear them, as explained by enclothed cognition: the effect clothing and associated symbolic meanings have on the psychological processes of the wearer. ${ }^{7}$ The term "enclothed cognition" is drawn from the idea of embodied cognition, which is the recognition of abstract concepts of symbols created from physical experiences. This means that as the mind creates modal representations for abstract concepts, physical experiences can trigger these representations through their symbolic meanings. As one such physical experience is wearing clothing, enclothed cognition suggests that wearing different forms of dress results in the embodiment of the representations associated with the clothing. ${ }^{8}$ It shows that clothing changes how we think, rather than just being a reflection of what we think. 
It is enclothed cognition that explains why uniforms can influence behaviours of individuals so dramatically. Uniforms function to transform the power of individuals or groups into authority for the governing structure. They are used to create order in the group while ensuring the goals of the organization will be met by instilling attributes of an ideal persona through practiced body techniques, which cover sociological, psychological, and biological aspects. This is done by creating and maintaining rules of wear through surveillance and policing of behavior while in uniform, or of uniform behaviour. ${ }^{9}$ Uniforms create a visual monopoly that ties an individual solely to the group, becoming a group emblem. Enclothed cognition acts on emblematic attributes, resulting in the internalization of uniform behaviour. Due to the visual nature of the emblem, the uniform acts as shorthand for the expectations of behaviour that the wearer is to live out and the viewer is to anticipate.

\section{The creation of a uniform then is a very powerful statement, presenting unity, or- ganization, and hierarchy. Schools have long used this tool in specific ways.}

Gendering of school uniforms required that uniform behaviour differed between students. School uniforms began in England as being exclusively male, and therefore the desired attributes were conceived as masculine attributes, such as leadership, achievement, and conformity, alongside more neutral attributes of pride and community. This meant that uniform practice for girls needed to reflect a different set of skills, for example self-negation. The uniforms largely promoted what was "normatively male and transgressively feminine." 10 To transition from schoolgirl to womanhood required that much of the body training instilled in schools be replaced with different societal standards, contrary to the expectations for boys. Having begun in 1552, school uniforms were well-entrenched in British practices by the Indian Residential School era. 
Beyond the desire to shape body techniques of Canadian Indigenous children to fit with European standards, uniforms were important in assimilation projects because clothing was a key component in civilizational theories, which dictated who was civilized. Of course, the system of civilization was designed to position the West as civilized and "Others" as uncivilized, or as civilizations in decay. The idea of a burden of civilization was created in which it was the duty of the West to stop the decay of other civilizations by teaching the "Others" the ways of the West. The burden of civilization was seen as a justification for colonization. Thus, what civilization was and how it would be taught were contradictory. Being "civilized" required "peaceful pursuits of trade, literature, and science," but the act of civilizing demanded obedience and discipline, which was enforced through punishments that were often violent. The civilizing process was counterproductive to the end goal of assimilation. Duncan Campbell Scott, the superintendent of the Department of Indian Affairs from 1913 to 1932, publically defined assimilation in the Canadian context. He stated, "I want to get rid of the Indian problem... Our objective is to continue until there is not a single Indian in Canada that has not been absorbed into the body politic, and there is no Indian question, and no Indian Department." Assimilation into the civilized nation of Canada would have been achieved when Indigenous people had become indistinguishable from white Canadians, a goal that was never reached. Yet, an illusion of success could be achieved. Fashion was the concept of civilization made physical, allowing for a hierarchy of civiliadvantage of by colonizing powers. ${ }^{15}$

\section{These theories made sense from a Western perspective, but Indig- enous worldviews in regards to dress were different.}

Though there are no sources containing a fully developed dress theory, by looking at Indigenous ontologies and epistemologies a fairly complete idea can be discerned. While Indigenous ontologies and epistemologies differed from nation to nation, there are similarities. For instance, nature is animate, including animals, plants as well as rocks, rivers, and places; nature is comprised of living spirits, complete with creative processes and energies; and, humanity is positioned equally, not above, creation and cosmos. ${ }^{16}$ Potawatomi Nation botanist, Robin Wall Kimmerer, states that in Indigenous ways of knowing "human people are often referred to as "the younger brothers of Creation. We say that humans have the least experience with how to live and thus the most to learn." 17 This 
is why the land is so important. Whereas land was property or capital to the settlers, to Indigenous people, it was everything. The land is a connection to the ancestors, the way of developing and knowing identity, a home to the human and nonhuman kin, a library of knowledge, and the source of all sustenance. Land is sacred, therefore could not be bought or sold but shared. It belonged to itself. This is true across Indigenous nations in North America.

Beyond the philosophy of "nature as a teacher," there is a reciprocal relationship with humanity. Nature sustains human life and humanity's responsibility is to respectfully follow the natural laws that sustain life through renewal ceremonies and mindful stewardship and sustainability practices. When hunting it is understood that there are animals who sacrifice themselves to sustain humanity by the hunter's hand. Swampy-Cree Elder Louis Bird explains that hunting is not just a battle of wits between human and animal, but is an agreement between the hunter and the animal. To respect this agreement and show proper gratitude, the hunter must use every part of the animal and not waste anything. ${ }^{18}$ This reciprocal and respectful relationship between humans and nature is important in understanding Indigenous relationships with their dress, in that clothing is made of plant fibres and animal hide.

From this perspective, humans are interconnected with the earth in many ways. Nature is not only an animate force and a teacher, but in death, human energy is transformed into energy of the land. In moving through life, the body and nature are in a relationship which is nourishing to both. Therefore, through the decomposition of the body into the primal elements, Indigenous relatives and ancestors are transformed into a living landscape, in both a biological and metaphoric truth. ${ }^{19}$ This "living process" is evident in Indigenous languages, which are verb based rather than noun based. If nature is animate they do rather than are, and Indigenous languages describe the experiences of an aware and active participation with the world. This is true of both Algonquian and Iroquoian languages, the two major language groups of Canadian First Nations. In these languages, words for specific animal hides are animate and the belief is that animals and humans transfer their energy and spirit to the earth and cosmos after death. ${ }^{20}$ 


\section{In this perspective, clothing has its own energy and is a symbol of identity not only to people, but a symbol to the natural world; particularly to the kin of the animal who gave its life for the creation of the dress.}

In Indigenous communities, the creation of dress was within the women's domain and they worked not only to dress their families, but to "maintain balance with the natural world." ${ }^{21}$ Wellmade clothing was a sign of respect to the animals, so the favour of their species would not be lost. Losing favour would cause hunters to jeopardize the agreements with the animals and their willingness to provide for humans through their sacrifice. Therefore, dress was even more important in providing for the community in that respectful adornment helped to maintain relations with the natural world, which would result in a successful hunt. ${ }^{22}$

Due to the transfer of the energy of the animal to dress, where Entwistle described body as the environment of the self, it can be said that in Indigenous theory clothing is another environment rather than an ornament for the body. ${ }^{23}$
The environment of the body is not simply interacting with other people and nature around it while cloaked in inanimate objects, but rather the body is an environment that first interacts with the animate dress most closely situated to it. Yet, as the transfer of energy and spirit can be seen in death, it can also be seen in life. These overlapping environments continuously exchange energy from each other, causing dress to possess something of the wearer as well. In some ways, this is a step beyond enclothed cognition. Enclothed cognition depends on the wearer recognizing what the dress symbolizes for the garments to then modify the behaviour of the wearer, whereas in Indigenous dress theory the dress does not simply represent attributes, but holds them. Clothing is not just presenting an identity, but encourages living in a good and respectful way. 
Taking this idea further, if culture is located on the body through dress and Indigenous culture is fundamentally linked to land, then land is also located on the body. Taking clothing, as was done to children entering residential schools, means taking connection to the land. Taking clothing means taking connection to the balance that was being created. Replacing this with unfamiliar clothing is forcing a new way of life beyond body techniques, introducing a new worldview that is vastly contradictory to Indigenous ways of knowing, being, and doing. While a depth of understanding of Indigenous dress theory was lacking amongst the men who set up the residential schools, they did know that by letting Indigenous dress remain, it would mean a failure to completely "civilize," which is why dress was stripped from the children entering these schools and replaced with Western-styled clothing.

The development and management of Indian Residential Schools was long. In the process of assimilation used to fulfil the perceived social responsibility towards Indigenous peoples as outlined in the Indian Act of 1876, with the ultimate aim to eliminate cultural differences and, essentially, to eradicate Indigenous peoples, education was seen to be the primary tool. ${ }^{24}$ The history of schools for Indigenous children in what would become Canada started as early as the 1630s, with Jesuit schools in Quebec. ${ }^{25}$ The attempts at schooling continued into the British era of rule, which started in $1760 .{ }^{26}$ Yet, what became known as Indian Residential Schools started in the 1880s, when the Canadian government began funding two types of schools, both with strong assimilation policies. Starting in 1883, industrial schools were established by the federal government. Industrial schools were larger and located near urban centers, teaching urban-associated trades. Boarding schools, which were a lower funded, less ambitious systems paralleling industrial schools, were located on or near a reserve and taught agriculture and basic manual skills alongside reading, writing, and arithmetic. ${ }^{27}$ Schools were created by the churches at a rapid pace, only then convincing the government to fund the schools already in use or in the process of being erected. While the Department of Indian Affairs could refuse the requests for funding, there is no record that they ever did. Costs skyrocketed. Even after a funding arrangement based on a per capita system was created in 1892, which would be in place until 1957, costs to build and maintain the schools continued to rise. This was despite the children bearing much of the cost of the schools through labour. Since the per capita rate was simply not enough to cover all expenses, the churches were also in debt. ${ }^{28}$

This financial issue was born out of poor attendance records. Recruitment was critical to the finances of the schools. Yet the per capita system itself was counterproductive in that it made the schools unattractive and thus more difficult to recruit and keep students in attendance, therefore less economical. This led to a spiral of problems. Due to the lower amount of funds provided, there was less food and more work for students to keep the schools running as additional staff could not be hired. As more staff could not be hired, and often the staff present were ill-trained and ill-suited to the work, there was also 
rampant abuse. In the scramble for recruits, sick children were admitted and in the combination of overcrowding, poor ventilation and sanitation, and lack of care, illness quickly spread amongst the children. With the poor food and overwork, death plagued the schools, with an estimation that 50 percent of the children who attended the schools died. ${ }^{29}$ Additionally, the focus of schools shifted from school completion to student enrollment. Due to the insufficient food, overwork, and the high mortality rate, recruitment became even more of a challenge. ${ }^{30}$ This led to coercion, or blaming of the victim, as the church and government assigned responsibility to Indigenous peoples for the failure of the system.

The industrial school system did not last the length of the Indian Residential School era, ending in 1922 with the closing of Father Lacombe's school at High River in the Northwest Territories. At this point, all schools were deemed to be residential schools. ${ }^{31}$ It was only after WWII that the system was reconsidered. In wake of fighting a war against racist ideologies and with criticism and resistance from Indigenous communities led by former students, an inquiry into the Indian Act was conducted in the latter half of the 1940s. ${ }^{32}$ A Special Joint Committee then put together recommendations to change the Indian Act. One of the twelve recommendations that was put forward for the 1951 Indian Act amendments was "that wherever and whenever possible Indian children should be educated in association with other children." 33 The Department of Indian Affairs devoted itself to achieving what was to be termed "integration." This plan allowed the federal government to shift its educational responsibilities to the provinces by closing Indian Residential Schools and having Indigenous children attend Day Schools or provincially-run schools. ${ }^{34}$ After the decision was made, the process of transition was still time consuming. As such, with the exception of funding schools run by Indigenous organizations, by 1986 the Department of Indian Affairs came to the end of running residential schools. The last school closed in $1996 .{ }^{35}$

As mentioned, dress was a part of the educational plan to "civilize" Indigenous children throughout the Indian Residential School era, and into integration.

To fully realize the impact of the residential school clothing, it is important to look at the accounts of what clothing was like and what it meant prior to attending the schools. 
Most notably, in relevant testimony, there is a connection between clothing and family, particularly maternal figures, as well as culture and security. Piita Irniq recalled, "My mother would sew all of the clothes that we had, you know, caribou clothing and things like that, sealskin clothing." To Irniq clothing had ties to the land, in that the materials were from the area around Repulse Bay where Irniq was born, hunted by Irniq's father initially and later himself. Additionally, they were created by his mother. Nazaire Azarie Bird, who went to St. Michael's School and Lebret Residential School in Saskatchewan from 1938 to 1951 , recalled dressing himself to go to school. "I slapped on my moccasins, my little rubbers, my hand-sewn pants, my hand-sewn shirt and hand-sewn jacket and I had a little fur hat." ${ }^{37}$ As previously noted, this method of creation was a symbol of balance and connection with the natural world and a means of living in a good way, allowing Indigenous peoples to exist in harmony with all their environments, from the environment of their clothing to the environment of the land. These statements also illustrate that similar clothing practices were employed across Canada by Indigenous peoples, either in that clothing was largely handmade, or tied to female family members, a practice that was also common in non-Indigenous communities during this time.

The first instance Indian Residential School Survivors remember clothing being used was for recruitment. A student who attended Gordon's Residential School in Saskatchewan noted, "the Anglicans, they would come out with what they called 'bale clothes.' They bring out bunch of clothes in a bale, like, a big bale. It was all used clothing and they'd give it to the women on the reserve here... that's the way they, they competed for us as people." 38 In 1949 the leaders within the Anglican head office recognized that dressing students returning home in the best available apparel "pleases the Indian parents and acts as 'bait' to encourage the parents to send more children to the schools." ${ }^{39}$ The practice only ended because the Indian School Administration was concerned about the expense. Evidently, the importance of dress in the residential school system began prior to the children arriving at the school and extended beyond their leaving.

Using clothing as recruitment was not always done though, and leaving for school was another moment in which dress was important. Rita Watcheston was from a poor family from Ochapowace in Saskatchewan who attended Lebret Residential School from 1949 to 1959 . She stated:

We were very poor. We never had clothes or anything. Then that one morning my dad picked us up and we went shopping. We all got a new set of clothes... early the next morning he woke us up and we had to take a bath and we had to put on these new clothes... All of a sudden a big black car pulled up and they told us to get in the back seat. We had no luggage; nothing. ${ }^{40}$

New clothing for Watcheston and her siblings would have been a sacrifice for their single father. Yet, he made sure that his children were clean and appropriately dressed in preparation for their departure, though they never had the privilege of new clothes before. It is likely that appearances were important, but also, arguably more im- 
portant was that the children were dressed in clothes that would last for the time they were away. It is hard to know which was true for each parent in similar instances, but as the practice of dressing children up is seen multiple times, and remembered by the Indian Residential School Survivors, it is important. It was an act of hope for wellness at the very least and a sign of love and care by the families of the children.

Not every child was dressed up or received new clothes before leaving for school. Harry McGillivary, who went to school in Prince Albert, Saskatchewan from 1959 to 1960, noted, "we came from a poor family. He just took us the way we were with the clothes we had. We had nothing else." ${ }^{41}$ Even still, the clothes the children had were a tie to the community, the last physical tie beyond the environment of the self.

Most survivor's accounts of dress cover the arrival at the schools. It was the traumatizing moment in which cultures clashed and the first lesson of the residential school was taught. The account of entering the schools are similar regardless of the institution. Campbell Papequash who attended the Catholic Indian Residential School in Kamsack, Saskatchewan in 1946, recounted:

...I was stripped of my clothes, the clothes that I came to residential school with, you know, my moccasins, and I had nice beautiful long hair and they were neatly braided by mother before I went to residential school... And after I was taken there they took off my clothes and then they deloused me... And then they cut off my beautiful hair. You know and my hair, my hair represents such a spiritual significance of my life and my spirit. And they did not know, you know, what they were doing to me. You know and I cried and I see them throw my hair into a garbage can, my long, beautiful braids... And I was shaved, bald-headed. And then after I had the shower they gave me these clothes that didn't fit, and they gave me these shoes that didn't fit and they all had numbers on them. ${ }^{42}$

Papequash describes not only the moment in which his dress was taken, but how that process was value-laden. Papequash's dress was treated as inferior. His hair was specifically attacked. Jennifer Craik points out that in school uniforms boys could not have long hair due to European connotations with immorality, slovenliness, or perhaps even a lack of discipline. ${ }^{43}$ This is a sharp contrast to Papequash's own description of the spiritual importance of his hair, which also contains a connection to his mother, who braided it. The story also recalls the presence of the numbers in their clothing. A number rather than a name, taking identity and a symbol of personhood. In addition to stripping clothing then, the staff was stripping bodily autonomy and replacing it with a sense of inferiority and dehumanization. Many accounts recall this specific moment, in which clothing was taken, hair was doused with either a white powder or oil and cut, cleaned, and then given clothes with numbers. Much of the testimony notes that the children did not know what was happening, particularly with the delousing, making the situation all the more confusing and degrading. ${ }^{44}$ 
Ideally, "[a]11 children would be... plainly clothed and simply fed." ${ }^{35}$ This was understood as key to "civilizing" and assimilation since early in the schooling process. The 1845 Bagot Report outlined the Committee of the Executive Council's recommendation that "a different kind of clothing to be distributed for that hitherto supplied, viz: something more resembling the European mode of dress." ${ }^{\text {"6 }}$ Therefore, had the ideal been obtained and sustained throughout the Indian Residential School era, children would have been clothed in plain European dress. Dress was not only important because of enclothed cognition, but because dress was used as a recognizable reflection of the success of assimilation. ${ }^{47}$ This is most clearly seen in photographs of children clothed in European dress that the churches and government used as propaganda communicating the success of the schools. While this includes the numerous images of children dressed in matching uniforms, smiling in front of school buildings, it is in the before and after photographs that the importance of dress is most evident. This includes a before and after image of Thomas Moore in 1896, who attended the Regina Indian Industrial School (Figure 1 and Figure 2). The staged images first depict Moore in women's Indigenous dress with long, braided hair, then Moore dressed in a disciplined and masculine military-styled uniform, hair cut short. In images like this, the picture of Quewich and his children are a similar example (Figure 3), where "the past and future of western Canada" were depicted. ${ }^{48}$

\section{These images relied primarily on the change of dress.}

Without assimilation acted out visually on the Indigenous body, there would be no tangible proof, no publishable propaganda to show that Indian Residential Schools were capable of doing what was expected of them. 


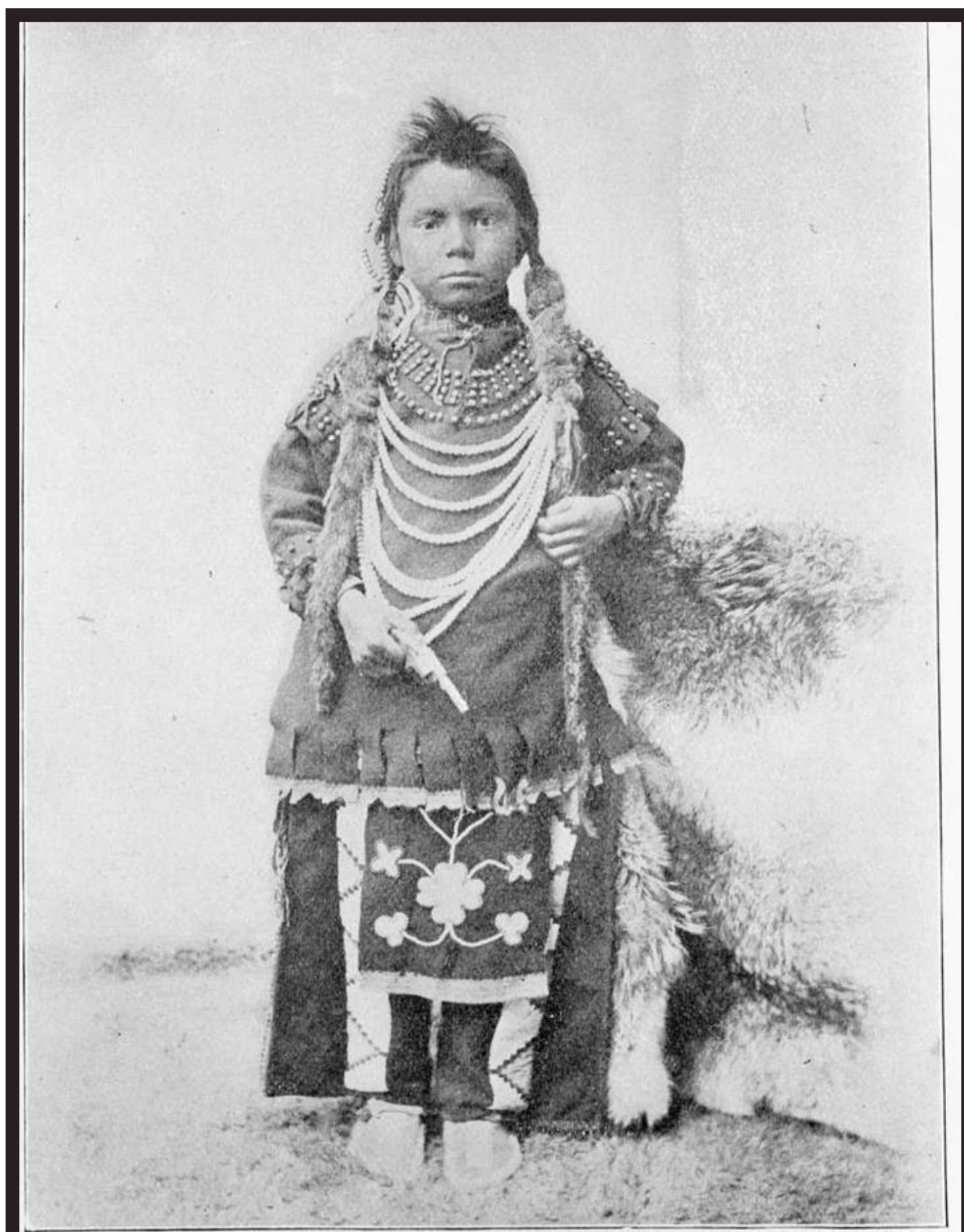

THOMAS MOORE, AS HE APPEARED WHEN ADMITTED TO THF REGINA INDIAN INDUSTRIAL SCHOOL. 


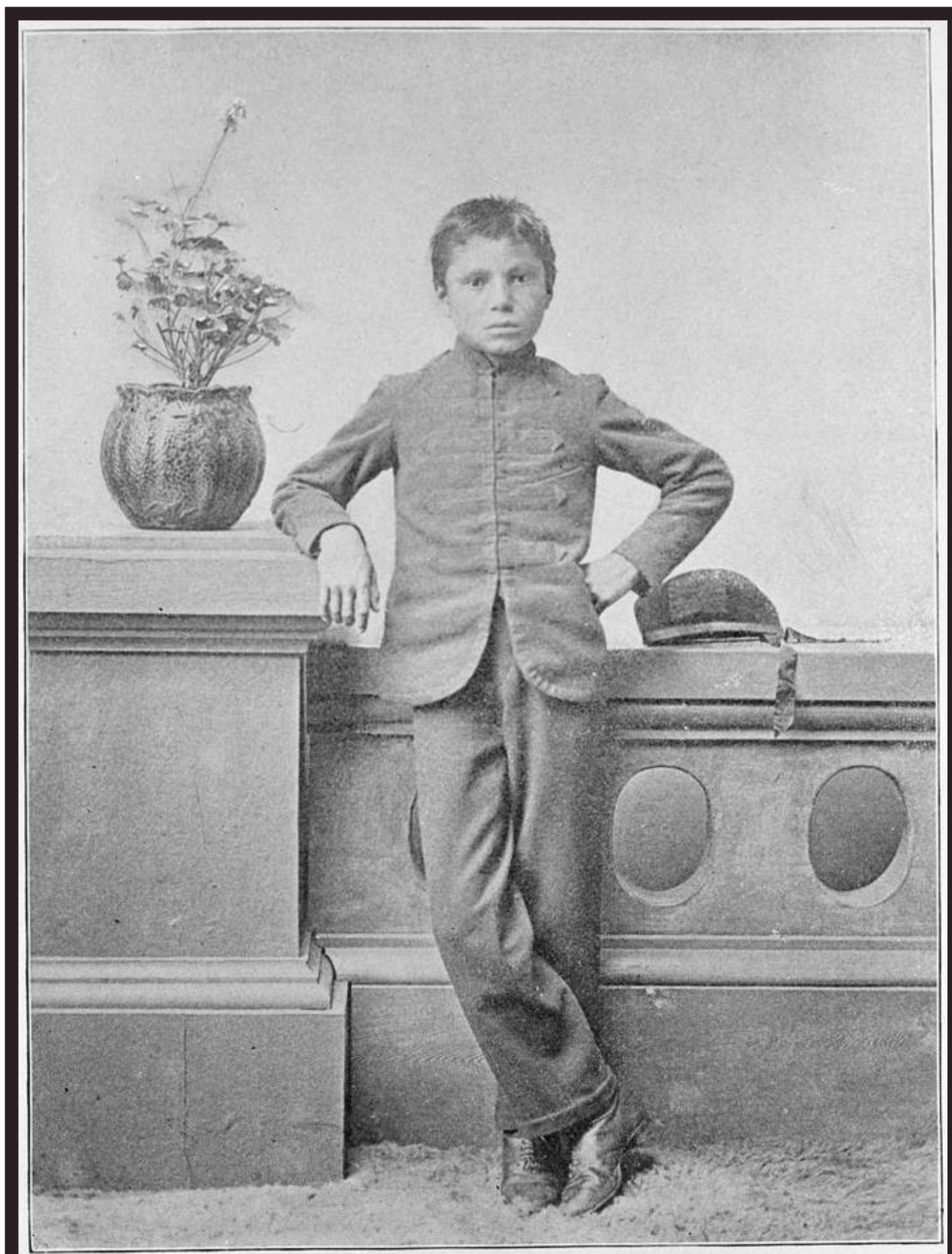

THOMAS MOORE, AFTER TUITION AT THE REGINA INDIAN INDUSTRIAL SCHOOL.

FIGURE 2 Thomas Moore After Picture. "Thomas Moore before and after admission to Regina Indian Industrial School." copied ca. 1980 (originally created ca. 1895), R-A8223 (2), Provincial Archives of Saskatchewan. 


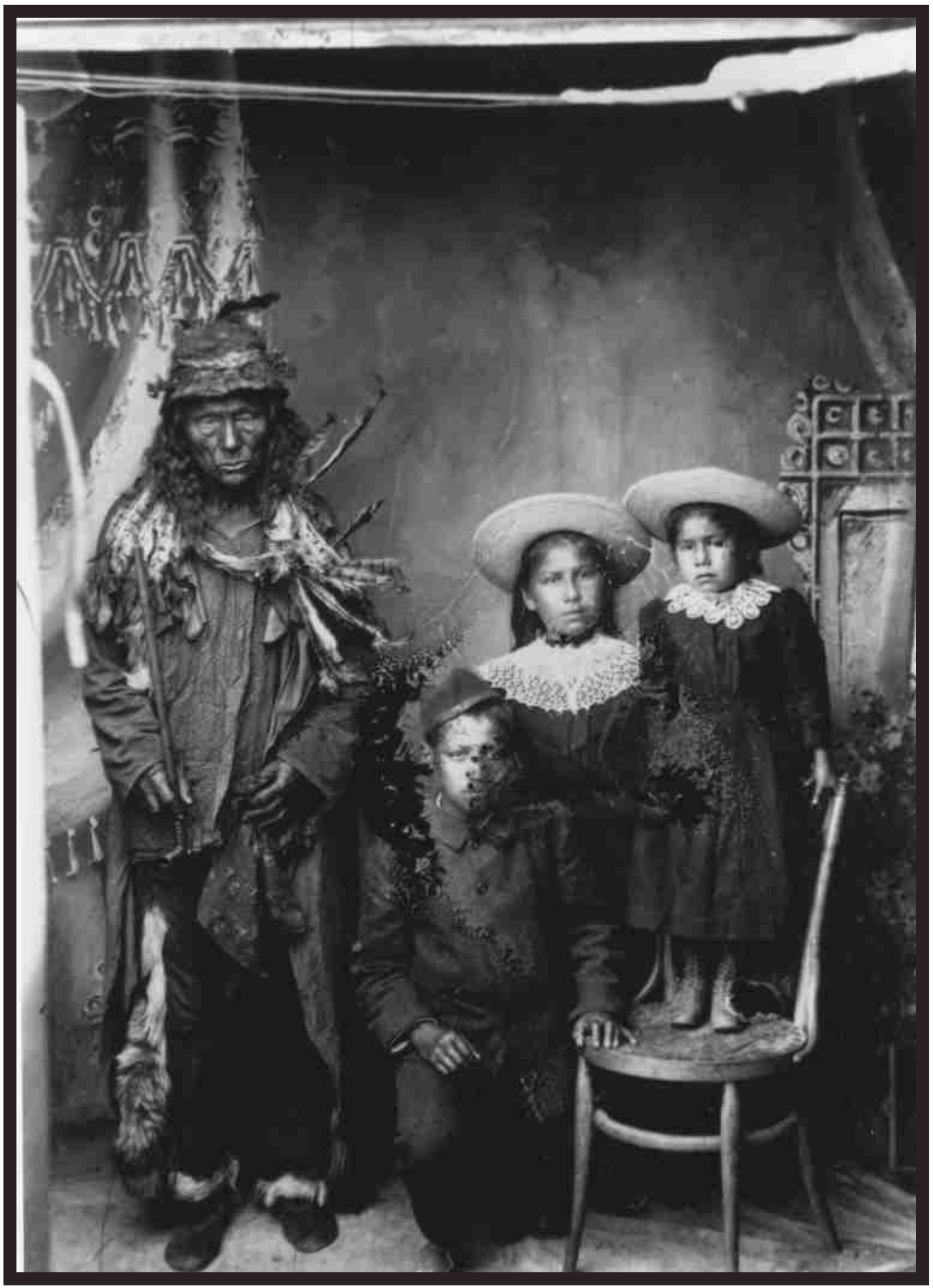

FIGURE 3 Quewich and his children. "Quewitch, as an elderly man, with his grandchildren," ca. 1900, R-A22202, Provincial Archives of Saskatchewan 
There would be no proof because, throughout the entirety of Indian Residential School history, it was understood that the schools were not succeeding in terms of educational achievement, trade or agricultural training, or caring for the children's basic needs. While it is noted that there were schools that managed to reach ideal standards for some periods of time, this was not the norm. ${ }^{49}$ As the children could easily be dressed in "civilized" clothing, this visual was the easiest way to present a successful image. Yet the images of Indigenous children in "civilized" dress were indeed fabricated. Isabelle Knockwood, who attended Shubenacadie Residential School in Nova Scotia from 1936 to 1947, wrote,

I remember how we used to have to change our prison-style, broadstriped blouses for dresses on the day of the photograph... As students we all knew that a special show was put on whenever the school came into contact with the outside world... Imelda Brooks remembers that, although she had no warm outdoor clothes at school, she was dressed in a new snow suit and boots to go to medical appointments in Halifax: “... The only time I have a nice warm new snowsuit and boots was when I had doctor appointments." ${ }^{50}$

As Brooks recalls, plain European dress was a fabrication that extended beyond the propaganda photographs and into excursions out into public. Outward appearance in public was seemingly one of the few aspects of residential schools that were sufficiently managed. For those who went into the schools, the reality was often vastly different. 
Variation in clothing was not always the case, as survivors recall the similarity in dress among students at various schools. Joseph Desjarlais, who attended two residential schools in the Northwest Territories said, "The first thing I noticed right off the bat when I got off the aircraft was all the kids were dressed exactly the same." ${ }^{56}$ Beverly Albrecht and George Francis have similar memories of matching uniforms, Albrecht saying that uniformity was "required," while Francis said he was "humiliated" by the garments. ${ }^{57}$ Dillon Stonechild stated that at the Qu'Appelle Indian School Residence, "We were all dressed the same. Maybe some of them were different colours and then we went and got a haircut." ${ }^{58}$ As Stonechild noted, even if the uniforms were not exactly the same, they were still similar enough to each other that the dress implemented could still be considered uniform.

As reality did not match the ideal, the uniforms in most cases, as noted, were insufficient. Only receiving two sets of clothes for the school year and an additional outfit for church was common. Joanne Morrison, who went to Shubenacadie Residential School, said, "We only had maybe two pair of pants, two socks, like two bras, two panties, and maybe two nightgowns, that's all we had. Sundays, it was a dressup dress..." 59 In some cases, like Samuel Ross' at Prince Albert All Saints School in Saskatchewan, they were only given one set of clothes. He said, "if you had your clothes torn or broken, that's the way they stayed." 60 Student's complaints about the clothing was known by the churches. Indeed, the Archbishop of Edmonton Primate of All Canada sent a telegram to the Prime
Minister on 19 December 1951, saying that it was "impossible for us to maintain even minimum standards in feeding clothing and supervision on present grants." The lack of proper clothing was therefore explicitly felt by students and well known to the churches, not only an immediate level by school staff, but by those in high positions within church hierarchies. While clothing was a responsibility of the churches managing the schools, the Department of Indian Affairs was the overseer. As pointed out, the Department of Indian Affairs did not perform enough inspections of schools, but that is not to say that they were not informed of the conditions. In 1908, the school at Shoal Lake had plenty of clothes donated by the Women's Foreign Missionary Society, and yet a report found "the children were not too warmly clad." 62 The Simes Report of 1943-4, a document created for the Department, stated that the students at Elkhorn School "were dirty and their clothes were disgraceful." ${ }^{3}$ These are only a few of the accounts made for or sent to the Department. The churches and the Department knew what state the students' dress was in, and nothing was done to remedy it, despite input from Indian Agents, hired inspectors, staff, and children. The poor condition of dress was systemic abuse, born from limited per capita grants and sustained through inaction of churches and the Department of Indian Affairs.

The children were also verbally, physically, and emotionally abused, and the abuse often revolved around the body and dress. Punishment was doled out for any number of reasons, including theft of food or interactions between boys and girls, and when it was, the abuse was often 
performed directly on the body. ${ }^{64}$ Thus, the students would have to remove their clothes. Indeed, punishment was used when clothes were not well cared for, on purpose or by accident, and therefore in some ways clothing was made more important than the students. This was especially true for children who wet the bed. Patricia Lewis, who attended Shubenacadie Residential School starting in 1957, was a frequent bed wetter as a child, and said her harshest punishment for such was Sister Gilberte nearly drowning her. "She dragged me all the way downstairs by my ear. She turned the hot water on in that tub and stripped me and put me in there... She put me under. I remember choking thinking I'm going to die and nobody is going to help me." ${ }^{55}$ Lewis's clothing was removed before her punishment. Sister Gilberte could have more easily attempted to drown her clothed, but Lewis was first stripped. The clothing and the continuously dirtying of it was considered to be so serious that Gilberte nearly killed a child. Wendy Lafond, who attended the Prince Albert Residential School in Saskatchewan, said their punishment for bed wetting was to "stand in the corner in our pissy clothes, not allowed to change." ${ }^{66}$ While the first instance included the body being exposed, the latter account used the dirtied clothing to humiliate the children. All this while students, at least at Shubenacadie, were banned from going to the washrooms in the night. ${ }^{67}$

Another instance in which dress was largely featured in punishment was when students tried to run away. It was punishment itself that caused many of the students to attempt running. Ken Lacquette stated his reason was, "They used to give us straps all the time with our pants down, they'd give us straps right in the public." 68 While this punishment was painful and humiliating, the punishment upon being returned often lasted longer. After being brought back, Melvin Jack, who went to Lower Post Residential school starting in 1954-5, stated the runaway boys returned to the schools "were brought in front of all the boys and their heads were shaved. All their hair was cut off. They were stripped down and they were whipped with the fibreglass rod..." ${ }^{69}$ Bev Sellars wrote that along with a strapping, runaways would be punished severely. "Some girls had their heads shaved, and the boys had to wear dresses." ${ }^{70}$ Being strapped and having their hair shaved off in front of the student population was a very common punishment for runaways. While the beatings seem an obvious and repeated choice for punishment, the hair cutting speaks to something else, a lasting humiliation, a violation of spirit.

Needless to say, in cases of sexual abuse, clothing was also removed partially or fully. Abuse was enacted on the body, like punishment. At times punishment and abuse were combined. Mary Vivier attended Fort Frances Residential School where the head priest, the acting principal, would take students to his office for strappings. "He'd remove our, our unders, our pants, our underpants. He would strap us, and he would rub us... Another strap, another fondling." 71 While in this instance a girl was abused, sexual abuse was not confined to the gender. Additionally, sexual abuse was committed by both men and women. In most, if not all instances, clothing was partially or fully removed. This too was a form of punishment, regardless of wheth- 
er or not it was framed that way by the perpetrators. Children who had little to no knowledge of sexuality were having it forced on them, their bodily autonomy violated. Clothing in many cases was the last suggestion of defense, and it was removed by others.

Beyond the poor condition of the garments, the care of clothing fell to the children, primarily the girls. The skills being taught, including sewing and laundering, were prioritized so that the children would be able to work in their own communities and further "civilize" others. In certain instances, learning to sew was positive. ${ }^{72}$ Of course, this was not true of all schools. Ellen Smith said she lacked skills upon returning to her home in Fort McPherson, Northwest Territories, naming sewing first in a list of such skills. ${ }^{73}$ Additionally, even if students did learn to sew, it was often to repair clothes at such a rate it was tedious overwork and proof of the inadequacy of dress. In 1893, Wadsworth inspected the Qu'Appelle School. Of the clothing he said, that "very great economy has been exercised in repairing the children's clothing, darning, patching and repairing blankets... much of it was worn after the poorest white person would have considered the garment worn out." ${ }^{74}$ In the circumstances, mending was also used as punishment, as girls at Spanish Indian Residential School would have to recycle shoe laces as a consequence for running away. ${ }^{75}$ The clothing that many of the students were working on turned out to be rags, insufficient prior to the mending, and to save them required an abundance of work.

Maintenance expected by students extended to the laundering of clothes, often done once a week. At St. Andrew's Anglican Mission Eunice Gray described the process. "We used to have to hang clothes up. It didn't matter how cold it was, we would have to go hang the clothes up. And before we went to bed we had to bring them all in and hang them up inside..." 76 While sewing was a skill that could be transferred into different spheres, these children were learning laundering on an institutional scale. While Gray used washboards to clean clothes in the 1940s, later laundering became dangerous with the introduction of industrial washing machines. Joanne Morrison Methot, who attended Shubenacadie Residential School, was injured while doing laundry because of her childish curiosity. "One time I was in there, and the thing was spinning, I don't know, to rinse the clothes, and I stuck my hand in there, and my hand twisted." ${ }^{77}$ Regardless of the method, as Verna Miller explained, laundering on an institutional scale did not equip her well for life after. "I had no clue, absolutely no clue about how to run a household because I was raised in an institution... I was doing 200 sheets of laundry once a week..."78 Like mending clothing, institutional laundering was not simply to teach female students to run a household, but to keep the schools viable.

Dress in Indian Residential Schools was perceived as a foundational component to civilizing Indigenous children by churches and government. It was first used as bait to win children to the school or a specific denomination, then used as a tool to display assimilative success. It included changing clothing and hair, while teaching disdain for the Indigenous body. In light of the ongoing issues, in 1938, the churches asked the Department of Indian Affairs to provide clothing for the schools. ${ }^{79}$ Yet, even into the integration plan dress was an issue. Indigenous students in public schools were 
mocked if they could not dress to the standard of their non-Indigenous peers, which was often the case due to continuing, now intergenerational, poverty. ${ }^{80}$ Therefore dress was an issue for the Department of Indian Affairs, the churches, and the students through the history of the Indian Residential Schools, and even into integration, remembered by many as another harmful component of assimilation.

\section{Considering all these factors reveals how dress negatively affected the children who attended the residential schools and the sig- nificant differences between Indigenous and Western worldviews.}

For Indigenous children, dress highlighted balance with and respect towards nature, ties to community, and living in a good way. This is seen in the testimony of Indian Residential School Survivors that describe dress prior to separation from the community, at most in the creation and care of traditional clothing, and at least in dress being given and cared for by parents. Living in a good way entailed a different lifestyle than Western ideals of the concept, which was encapsulated in the concept of civilization and the hierarchy of beings. Indeed, the contradictions in dress theory were vast. Whereas there was the Western belief that "clothes make the man," Indigenous peoples believed that clothes made a relationship. As dress was rooted within Indigenous ontologies and epistemologies, dress too needed to be changed in order for children to be "civilized."

Considering Lynch and Strauss' theory that that dress "becomes part of who we think we are," the idea that wearing European dress would make a person more acceptably "civilized" is not necessarily far-fetched. ${ }^{81}$ As the schools targeted the young, the implementation of uniforms in Western styles were not only to present a successful and civilized image, but to manage social and 
inner behaviours as cheaply as possible. If dress "becomes part of who we think we are," the staff running the schools, indeed Indian policy, missed the civilized mark. As Milloy explains,

Right from the outset... the "circle of civilized conditions" did not live up to its name. It did not because it could not, Government and church correspondence and reports reveal that there was, as an inherent element of the vision, a "savagery" in the mechanics of civilizing children... the basic premise of re-socialization was violent. "To kill the Indian" in the child, the Department and churches aimed at severing the artery of culture that ran between Aboriginal generations. ${ }^{82}$

The inadequate clothing was not teaching children to be "civilized" at all, but revealing the savagery inherent in the system. This occurred in a number of different ways.

Indian Residential Schools depended on enclothed cognition. Western-styled dress was supposed to represent and therefore influence children to practice discipline and a specific morality. Due to the children's already established ontology, taught by their parents and communities, stripping their clothing and replacing it with uniforms was seemingly meant to disorientate children's established understanding of dress so they could be reoriented to understand what European dress represented. ${ }^{83}$ Looking at the testimony of student arrivals, the moment was traumatic and shameful not primarily of dress but of body, particularly hair. In the delousing and cutting of hair, there was the belief passed to the children that they were dirty. Shearing hair was a punishment that they deserved upon arriving at the school for being who they were, Indigenous, which was reinforced when hair-cutting was specifically used as a punishment later. In contrast to dress prior to school, there is a clear sense of loss, a connection to the children's communities that was being severed. The replacement dress was not seen as superior in any way, so even at the initial moment of transition, Western-style dress was immediately perceived as lesser by students. Paired with the bestowing of numbers in place of names, humanity was stripped as well as clothes. Arrival was teaching children that their Indigenous bodies were dirty and not their own, and the replacement clothing revealed that school would be lesser than their homes.

The replacement uniforms were not only worse than the dress just taken from the students, but insufficient for everyday wear and weather. Discomfort was intimately and constantly felt, creating a poor relationship between the students and their dress.

\section{Whereas dress is fundamentally meant to protect the body, the uniforms that were provided did not create safety.}


They taught an experience of scarcity, which was once again due to the student's inherent Indigeneity. The deficit was highlighted particularly by the presentation of plain European-styled dress to the public at church, in hospitals, and through the proliferated propaganda images that required the children to dress in clothing much nicer than their usual garb. ${ }^{84}$ The propagandistic lie may have "proven" a level of civilization to bureaucrats and the public, but to the children it likely only highlighted that dressing well was not their norm. Certainly some children came from homes too poor to properly dress them as well, but in the schools they were all made equal not in safety and protection, but in deprivation. In these schools, clothing was deliberately not tied to culture or community, additionally making it a deprivation of self. This, compounded with abusive discipline, furthering shame.

Clothing was a thin form of protection that could easily be removed as punishment was enacted directly on the body. It communicated a statement of the worth of European dress in comparison to the worth of the Indigenous body. The message was: there was nothing wrong with the garments, it was the body within the clothing that was wrong. As the abuse was often done publicly, this intensified shame, making not only a perceived wrong known to all, but also the supposed wrong-doers body visible and known to all. Shame of body can be clearly seen in William George Lathlin's recollection of the time. He said,

My skin was kind of brown and I tried to wipe the skin off my left hand. You can see the scar today. It's still there. It was all red. It really messed me up because I didn't --- I couldn't figure out why my family, my grandparents and my mother and father were called evil and what they did was evil and all that. I couldn't. ${ }^{85}$ 
The uniforms as a means of managing behaviours was not creating a civilized individual and social life, but creating shame and a sense that Indigeneity was evil. Like Milloy stated, this was part of the inherent savagery of the civilizing plan. ${ }^{86}$ The benefit of dressing properly was prevention of punishment, not the promotion of pride and self-worth, or community, or the protection of the body from the elements. Body techniques had less to do with how to move through the world confidently and more to do with preservation of dress and self-negation.

Craik describes uniforms as being normatively masculine and transgressively feminine. ${ }^{87}$ It could be argued that whereas uniforms were normatively Western, they were transgressively Indigenous. Indigenous dress was seen as a threat in part due to "excessive individuality of Aboriginal society. Unbridled individualism, manifest in boisterous, decorative display, which broke the bounds of decorum and thus signaled the potentiality of lawlessness, was the core of savagery." ${ }^{88}$ School uniforms were created in the era of sumptuary laws, their point being to have poor boys in a charitable school dressed cheaply and distinctively. It was to show the boys and the community around them their place in the social hierarchy. ${ }^{89}$ In many Indigenous societies, with community-based social organization void of rigid hierarchies amongst humanity and all creation, there was no need for uniforms. With dress made to create balance and relationship with nature, uniformity was not a necessity. Yet Indigenous students were expected to always wear transgressive garments. They were not to grow out of dressing within the Western hierarchy, but were to wear a sort of uniform all their lives.

In the history of Indian Residential Schools clothing was a dignity that the children were often denied, which could not have taught civilization. If dress "becomes part of who we think we are," then the clothing at residential schools were to teach Indigenous children shame of their inherent and unchangeable Indigenousness and Indigeneity, that is shame of their own bodies and cultures, while simultaneously placing the worth of non-Indigenous objects above their own self-worth. It was not teaching civilization, but dehumanization. As Robert Tomah, who attended Lejac starting in 1966, described,

It was just like when they took off our bush clothes, when they undressed us, they didn't realize I guess that they were undressing our dignity and stepping on it. They didn't have vision enough to see that... But they were revising our minds where we were not ourselves anymore. ${ }^{90}$

Culture and dignity were embedded in the clothing Indigenous children wore from home. The physical act of forcefully removing dress, at times the last material piece of home a child had, was disrespecting not simply the Indigenous clothes, but the child and their identity. 


\section{Further, as "body as environment of the self" allows the creation of relationship with the world, first through the environment of clothing, what were the children being taught about the world?}

That the world is uncomfortable, harsh, and does not care for their wellbeing. This is a teaching that is contradictory to Indigenous pedagogies that state that people and nature are in a respectful reciprocal relationship, where there is abundance and where animals sacrifice themselves for sustenance. While Indigenous dress was created and worn to create balance in the world, residential school clothing created unbalance, cutting the children off from the land, from their people and their culture in a way that undermined their self-worth and dignity. As is well known, the trauma of residential schools and of European ideas of civilization, created an abundance of issues on reserves and resulted in intergenerational trauma. Of course, dress itself was only one aspect of this trauma, but as the first environment the body interacts with it is an important one.

The purpose of implementing European-styled uniforms in Indian Residential Schools was to promote and enforce assimilation. While falsely proven through propaganda, the uniforms did not promote assimilation but rather discomfort, shame, and fear. The clothing was too insufficient, the punishment and abuse too harsh, and the care too difficult for students to absorb traditional body techniques and uniform practice, that is to learn respect or admiration for Western civilization. Instead, students were cut off from the last objects from home, removing their connection to culture, community, and land. As such, identity was confused and students experienced disorientation from their communities and white communities, leaving them in limbo between the two and causing trauma, but not assimilation. The assimilation program did not work. Since, there has been healing and a return to communities and cultural ways. What was lost was not all lost permanently, but there is a continuing process of revitalization and reconciliation that must be actively sought by Indigenous and non-Indigenous peoples alike. 
1 Truth and Reconciliation Commission of Canada, A Knock at the Door (Winnipeg: University of Manitoba Press, 2016), 3.

2 Truth and Reconciliation Commission of Canada, A Knock at the Door (Winnipeg: University of Manitoba Press, 2016), 3.

3 Joanne Entwistle, “The Dressed Body” In Body Dressing, (Oxford: Berg, 2001), 41.

${ }^{4}$ Entwistle, 33.

${ }^{5}$ Annette Lynch and Mitchell D. Strauss, Changing Fashion (Oxford: Berg, 2007), 14.

${ }^{6}$ Joanne Entwistle and Elizabeth Wilson, "Introduction." In Body Dressing. (Oxford: Berg, 2001), 4.

7 Hajo Adam and Adam D. Galinsky, "Enclothed Cognition." Journal of Experimental Social Psychology no. 48 (2012), 919.

8 Adam and Galinsky, "Enclothed Cognition,” 919.

9 Jennifer Craik, Uniforms Exposed: From Conformity to Transgression (Oxford: Berg, 2005) 4-5, 52.

${ }^{10}$ Craik, Uniforms Exposed, 68.

11 Brett Bowden, The Empire of Civilization: The Evolution of an Imperial Idea, (Chicago: University of Chicago Press, 2009), 41-46. Georg Simmel argued that "primitive races" had no fashion because the desire for union negated the desire for differentiation, which drove change within dress. George Simmel, "Fashion," The American Journal of Sociology 62, No. 6, (May, 1957), 545-546.

12 Bowden, The Empire of Civilization, 121. John S. Milloy, A National Crime (Winnipeg: The University of Manitoba Press, 1999), 43.

${ }^{13}$ Quoted in E. Brian Titley, A Narrow Vision: Duncan Campbell Scott and the Administration of Indian Affairs in Canada, (Vancouver: University of British Columbia Press, 1986), 50.

14 This aligns with the Encyclopedia Britannica definition of assimilation, which describes it as "the process whereby individuals or groups of differing ethnic heritage are absorbed into the dominant culture of a society. The process of assimilating involves taking on the traits of the dominant culture to such a degree that the assimilating group becomes socially indistinguishable from other members of the society." Elizabeth Prine Pauls, "Assimilation." Encyclopædia Britannica. Encyclopædia Britannica, inc., August 21, 2019. https://www.britannica.com/topic/assimilation-society.

15 Sandra Niessen, "Interpreting 'Civilization' through Dress." In Berg Encyclopedia of World Dress and Fashion: West Europe, edited by Lise Skov, 39-44. (Oxford: Berg, 2010), 39-44.

${ }^{16}$ Gregory Cajete, Native Science: Natural Laws of Interdependence. (Santa Fe: Clear Light Publishers, 2000), 21.

17 Robin Wall Kimmerer, Braiding Sweetgrass: Indigenous Wisdom, Scientific Knowledge and Teachings of Plants. (Washington: Milkweed Editions, 2013), 9, 17.

${ }^{18}$ Louis Bird and Roland Bohr, "Views of a Swampy-Cree Elder on the Spiritual Relationship between Hunters and Animals," in The Culture of Hunting in Canada ed. Dale G. Miner and Jean Manore. (Vancouver; UBC Press: 2007), 92, 102-103.

${ }^{19}$ Cajete, Native Science, 21, 25. 
${ }^{20}$ Sherry Farrell Racette, "Looking for Stories and Unbroken Threads: Museum Artifacts as Women's History and Cultural Legacy," in Restoring the Balance: First Nations Woman, Community, and Culture. Eds. Gail Valaskakis, Dion Guthrie, Madeleine Stout, and Eric Guimond. (Winnipeg: University of Manitoba Press, 2000), 287. An example in Anishinaabe is amikwayaan, which is beaver skin, and waawaabkeshiwayaan, a deer hide, both of which are nouns, and yet still recognize the animate nature of the hides. This also extends to tanned hides, which is asekaan. Likewise, in Cree atibkowaya and apismoswayan are animate, which are caribou hide and deer hide respectively.

${ }^{21}$ Farrell Racette, 286-7.

${ }^{22}$ Farrell Racette, 287.

23 Entwistle, "The Dressed Body," 41.

${ }^{24}$ Milloy, A National Crime, 33.

25 J.R. Miller, Skyscrapers Hide the Heavens, (Toronto: University of Toronto Press, 2000), 64-5.

${ }^{26}$ Milloy, A National Crime, 14-15.

${ }^{27}$ Milloy, 7.

${ }^{28}$ Milloy, 52-6, 61-6.

29 J.R. Miller, Shingwauk's Vision: A History of Native Residential Schools, (Toronto: University of Toronto Press, 1996), 133, 123-128. According the TRC it is unlikely a precise percentage or number of children who died will ever be developed due to the gaps in the historical record. The Truth and Reconciliation Commission of Canada. Canada's Residential Schools: The History, Part 1 Origins to 1939. (Montreal \& Kingston: McGill-Queen's University Press, 2015), 376.

${ }^{30}$ Miller, Shingrwauk's Vision, 133, 123-128.

${ }^{31}$ Milloy, A National Crime, 51-2.

${ }^{32}$ Miller, Shingrwauk's Vision, 377-8.

${ }^{33}$ B. Neary, Memorandum to the Director, 29 November 1949, NAC RG 10, Vol. 8233, File 1/6-1 (1). MR C 14160, quoted in Milloy, A National Crime, 189.

${ }^{34}$ Milloy, A National Crime, 190.

${ }^{35}$ J.R. Miller, "Residential Schools in Canada."The Canadian Encyclopedia, October 12, 2012. https://www.thecanadianencyclopedia.ca/en/article/residential-schools.

${ }^{36}$ The Truth and Reconciliation Commission of Canada. The Survivors Speak: A Report of the Truth and Reconciliation Commission of Canada. (Winnipeg: The Truth and Reconciliation Commission of Canada, 2015), 7.

${ }^{37}$ Legacy of Hope Foundation, "Residential School Survivor Stories," Where Are the Children?, 2001, http://wherearethechildren.ca/en/stories.

38 “The Truth and Reconciliation Commission of Canada. The Survivors Speak, 17.

${ }^{39}$ Miller, Shingrwauk's Vision, 299.

${ }^{40}$ Legacy of Hope Foundation, "Residential School Survivor Stories," Where Are the Children?, 2001, http://wherearethechildren.ca/en/stories/.

${ }^{41}$ Legacy of Hope Foundation.

${ }^{42}$ The Truth and Reconciliation Commission of Canada. The Survivors Speak, 32. 
${ }^{43}$ Craik, Uniforms Exposed, 53.

${ }^{44}$ The Truth and Reconciliation Commission of Canada. The Survivors Speak, 31-41: Nellie, Ningewance 31-2, Rachel Chakasim 34, Lynda Pahpasay 38, Verna Kirkness 39, Alice Quinney 39, Elaine Durocher 41, Brian Rae 41, Julianna Alexander $41 .{ }^{45}$ Collins. "Historic Retrievals," 72.

${ }^{45}$ Milloy, A National Crime, 15.

${ }^{46}$ Charles Bagot, "Report on the Affairs of the Indians in Canada, Laid Before the Legislative Assembly, 20th March, 1845.” The Government of Canada. (1845), Appendix (EEE).

${ }^{47}$ Miller, Shingwauk's Vision, 195, 297-298.

${ }^{48}$ Miranda J. Brady and Emily Hiltz, "The Archeology of an Image: The Persistent Persuasion of Thomas Moore Keesick's Residential School Photographs." TOPIA: Canadian Journal of Cultural Studies, 37, No. 37 (2017), 63, 68, 74.

${ }^{49}$ Milloy, A National Crime, 100-101. In 1920 the Crowfoot Catholic Boarding School, formerly criticized by Bryce in 1909, achieved a high standard of health. Dr. F.A. Corbett described the children as were "well fed and plainly clothed, clean and wholesome standing erect and soldierly, strong and vigorous and would compare well with the children of any school."

${ }^{50}$ Isabelle Knockwood, “Out of the Depths, 2001.” In Strange Visitors, ed. Keith D. Smith, (Toronto: University of Toronto Press, 2014), 183.

${ }^{51}$ The Truth and Reconciliation Commission of Canada. Canada's Residential Schools, 511.

${ }^{52}$ Milloy, A National Crime, 74-5.

${ }^{53}$ J. Smith to Assistant Deputy and Secretary, 8 February 1918 NAC RG 10, Vol. 3918, File 116659-1, MR C 10161, quoted in Milloy, A National Crime, 105.

${ }^{54}$ Miller, Shingwauk's Vision, 298. Variation was persistent, except in the aftermath of WWI, when surplus military uniforms were bought and cut down to the children's sizes. After these uniforms were worn out, variation largely returned to the system, as did entirely insufficient clothing.

${ }^{55}$ Library and Archives Canada, RG73, Volume 139, File no. 1-21-13, Part 1. Convict Labour.

${ }^{56}$ Legacy of Hope Foundation, "Residential School Survivor Stories," Where Are the Children?, 2001, http://wherearethechildren.ca/en/stories/.

${ }^{57}$ Legacy of Hope Foundation. Albrecht attended the Mohawk Institute in Ontario from 1966 to 1970. Francis attended Shubenacadie starting in 1951. The uniform he wore was a second hand RCMP uniform, the boot soles "right on the sole."

${ }^{58}$ Legacy of Hope Foundation.

${ }^{59}$ The Truth and Reconciliation Commission of Canada. The Survivors Speak, 45.

${ }^{60}$ Legacy of Hope Foundation, "Residential School Survivor Stories," Where Are the Children?, 2001, http://wherearethechildren.ca/en/stories/. 
61 Indian Affairs (Domestic) - General - Prime Minister's Signature, 1950, Library and Archives Canada Ottawa, Privy Council Office Fonds, Series 4377069 - Central registry files, Subseries 4377119 - Records maintained in the central registry prior to 1953, Volume 164. Accessed 25 November 2018. https://nctr.ca/scripts/mnimain. dll? $184879596 / 1 / 1 / 25076$ ? record \&datbase $=$ desc acc view.

${ }^{62}$ The Truth and Reconciliation Commission of Canada. Canada's Residential Schools, 512 .

${ }^{63}$ Milloy, A National Crime, 114.

${ }^{64}$ Legacy of Hope Foundation, "Residential School Survivor Stories," Where Are the Children?, 2001, http://wherearethechildren.ca/en/stories/. The Truth and Reconciliation Commission of Canada. The Survivors Speak, 95.

${ }^{65}$ Legacy of Hope Foundation, "Residential School Survivor Stories", Where Are the Children?, 2001, http://wherearethechildren.ca/en/stories/.

${ }^{66}$ The Truth and Reconciliation Commission of Canada. The Survivors Speak, 60.

${ }^{67}$ The Truth and Reconciliation Commission of Canada. The Survivors Speak, 61.

${ }^{68}$ The Truth and Reconciliation Commission of Canada. The Survivors Speak, 133. Laquette attended schools in Brandon and Portage la Prairie, Manitoba.

${ }^{69}$ Legacy of Hope Foundation, "Residential School Survivor Stories," Where Are the Children?, 2001, http://wherearethechildren.ca/en/stories/.

${ }^{70}$ Bev Sellars, They Called Me Number One, (Vancouver: Talonbooks: 2013), 96.

${ }^{71}$ The Truth and Reconciliation Commission of Canada. The Survivors Speak, 155.

${ }^{72}$ Legacy of Hope Foundation, "Residential School Survivor Stories," Where Are the Children?, 2001, http://wherearethechildren.ca/en/stories/. Watcheson became a seamstress as an adult due to the skills she learned at school.

${ }^{73}$ The Truth and Reconciliation Commission of Canada. The Survivors Speak, 107.

${ }^{74}$ The Truth and Reconciliation Commission of Canada. Canada's Residential Schools, 513.

${ }^{75}$ Miller, Shingrwauk's Vision, 265.

${ }^{76}$ Legacy of Hope Foundation, "Residential School Survivor Stories," Where Are the Children?, 2001, http://wherearethechildren.ca/en/stories/.

${ }^{77}$ The Truth and Reconciliation Commission of Canada. The Survivors Speak, 82.

${ }^{78}$ Legacy of Hope Foundation, "Residential School Survivor Stories," Where Are the Children?, 2001, http://wherearethechildren.ca/en/stories/.

${ }^{79}$ The Truth and Reconciliation Commission of Canada. Canada's Residential Schools, 513-15.

${ }^{80}$ Miller, Shingrwauk's Vision, 397.

${ }^{81}$ Lynch and Strauss, Changing Fashion, 14.

${ }^{82}$ Milloy, A National Crime, 41-2.

${ }^{83}$ Milloy, 37.

${ }^{84}$ Knockwood, “Out of the Depths, 2001,” 183. 
${ }^{85}$ Legacy of Hope Foundation, "Residential School Survivor Stories," Where Are the Children?, 2001, http://wherearethechildren.ca/en/stories/.

${ }^{86}$ Milloy, A National Crime, 41-2.

${ }^{87}$ Craik, Uniforms Exposed, 68.

${ }^{88}$ Milloy, A National Crime, 124.

${ }^{89}$ Nathan Joseph, Uniforms and Nonuniforms: Communication Through Clothing (New York: Greenwood Press, 1986), 65-9, 56.

${ }^{90}$ Legacy of Hope Foundation, "Residential School Survivor Stories," Where Are the Children?, 2001, http://wherearethechildren.ca/en/stories/. 
Adam, Hajo and Galinsky, Adam D. "Enclothed Cognition.” Journal of Experimental Social Psychology no. 48 (2012), 918-925.

Bagot, Charles. "Report on the Affairs of the Indians in Canada, Laid Before the Legislative Assembly, 20th March, 1845." The Government of Canada. (1845), Appendix (EEE).

Bird, Louis and Bohr, Roland. "Views of a Swampy-Cree Elder on the Spiritual Relationship between Hunters and Animals," in The Culture of Hunting in Canada edited by Miner, Dale G. and Manore, Jean. 89-104. British Colombia: UBC Press, 2007

Bowden, Brett, The Empire of Civilization: The Evolution of an Imperial Idea. Chicago: University of Chicago Press, 2009.

Brady, Miranda J. and Hiltz, Emily. “The Archeology of an Image: The Persistent Persuasion of Thomas Moore Keesick's Residential School Photographs.” TOPIA: Canadian Journal of Cultural Studies, 37, No. 37 (2017).

Cajete, Gregory. Native Science: Natural Laws of Interdependence. Santa Fe: Clear Light Publishers, 2000.

Craik, Jennifer. Uniforms Exposed: From Conformity to Transgression. Oxford: Berg, 2005.

Entwistle, Joanne. "The Dressed Body” In Body Dressing. Oxford: Berg, 2001.

Entwistle, Joanne and Wilson, Elizabeth. "Introduction" In Body Dressing. Oxford: Berg, 2001.

Farrell Racette, Sherry. "Looking for Stories and Unbroken Threads: Museum Artifacts as Women's History and Cultural Legacy," in Restoring the Balance: First Nations Woman, Community, and Culture. Eds. Gail Valaskakis, Dion Guthrie, Madeleine Stout, and Eric Guimond. (Winnipeg: University of Manitoba Press, 2000)

Indian Affairs (Domestic) - General - Prime Minister's Signature, 1950, Library and Archives Canada Ottawa, Privy Council Office Fonds, Series 4377069 - Central registry files, Subseries 4377119 - Records maintained in the central registry prior to 1953, Volume 164. Accessed 25 November 2018. https://nctr.ca/scripts/ mnimain.dll? 184879596/1/1/25076? record\&datbase=desc acc view.

Joseph, Nathan. Uniforms and Nonuniforms: Communication Through Clothing. New York: Greenwood Press, 1986.

Knockwood, Isabelle. “Out of the Depths, 2001.” In Strange Visitors, edited by Keith D. Smith, (Toronto: University of Toronto Press, 2014), 177-186.

Legacy of Hope Foundation, "Residential School Survivor Stories,"Where Are the Children?, 2001, http://wherearethechildren.ca/en/stories/.

Library and Archives Canada, RG73, Volume 139, File no. 1-21-13, Part 1. Convict Labour.

Lynch, Annette and Strauss, Mitchell D. Changing Fashion. Oxford: Berg, 2007. 
Miller, J.R. "Residential Schools in Canada."The Canadian Encyclopedia, October 12, 2012. https://www.thecanadianencyclopedia.ca/en/article/residential-schools.

Miller J.R., Shingwauk's Vision: A History of Native Residential Schools. Toronto: University of Toronto Press, 2000.

Miller, J.R., Skyscrapers Hide the Heavens. Toronto: University of Toronto Press, 2000.

Milloy, John S. A National Crime. Winnipeg: The University of Manitoba Press, 1999.

Niessen, Sandra. "Interpreting “Civilization”Through Dress." In Berg Encyclopedia of World Dress and Fashion: West Europe. Edited by Lise Skov. Oxford: Berg, 2010.

Pauls, Elizabeth Prine. “Assimilation.” Encyclopædia Britannica. Encyclopædia Britannica, inc., August 21, 2019. https://www.britannica.com/topic/assimilation-society.

Provincial Archives of Saskatchewan, "Thomas Moore before and after admission to Regina Indian Industrial School.” copied ca. 1980 (originally created ca. 1895), R-A8223 (1), Provincial Archives of Saskatchewan.

Provincial Archives of Saskatchewan, "Thomas Moore before and after admission to Regina Indian Industrial School.” copied ca. 1980 (originally created ca. 1895), R-A8223 (2), Provincial Archives of Saskatchewan.

Provincial Archives of Saskatchewan, "Quewitch, as an elderly man, with his grandchildren,” ca. 1900, R-A22202, Provincial Archives of Saskatchewan.

Sellars, Bev. They Called Me Number One. Vancouver: Talonbooks, 2013.

Simmel, George. "Fashion," The American Journal of Sociology 62, No. 6, (May, 1957), $541-558$.

Titley, E. Brian. A Narrow Vision: Duncan Campbell Scott and the Administration of Indian Affairs in Canada, (Vancouver: University of British Columbia Press, 1986).

Truth and Reconciliation Commission of Canada. A Knock at the Door. Winnipeg: University of Manitoba Press, 2016.

The Truth and Reconciliation Commission of Canada. Canada's Residential Schools: The History, Part 1 Origins to 1939. Montreal \& Kingston: McGill-Queen's University Press, 2015.

The Truth and Reconciliation Commission of Canada. The Survivors Speak: A Report of the Truth and Reconciliation Commission of Canada. Winnipeg: The Truth and Reconciliation Commission of Canada, 2015.

Wall Kimmerer, Robin. Braiding Sweetgrass: Indigenous Wisdom, Scientific Knowledge and Teachings of Plants. Washington: Milkweed Editions, 2013. 


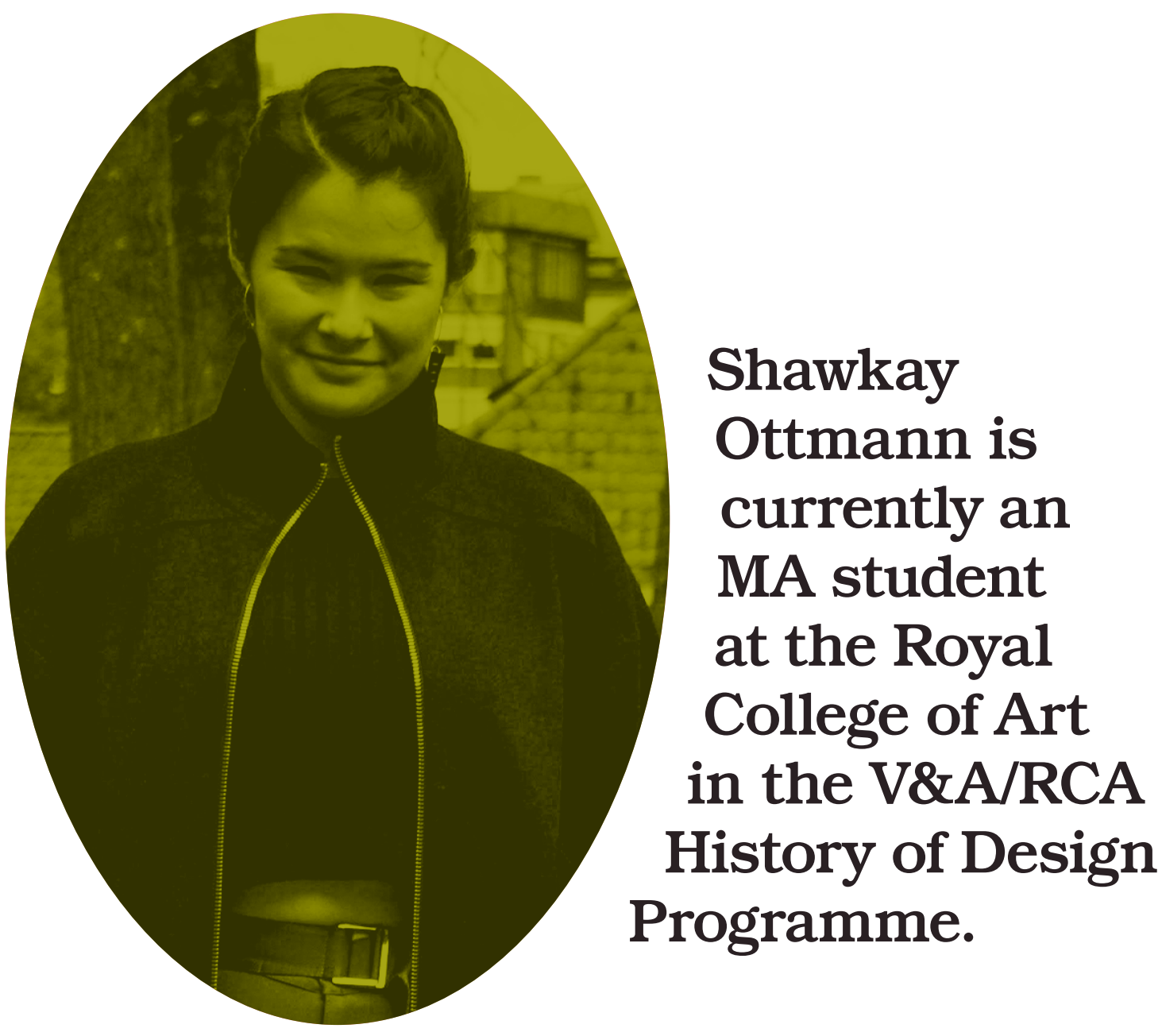

She graduated from Ryerson University with a Major in History and a Minor in Fashion Design in 2019. She is Anishinaabe from Fishing Lake First Nation in Saskatchewan, as well as British, German, Polish, and Norwegian. In the past, Shawkay has worked as a research assistant, aiding a professor research articles on Indigenous methodologies and Indigenizing the academy, along with researching Indigenous participation in the First and Second World War for the Juno Beach Centre. In her own name, Shawkay has been published writing about Indigenous participation in D-Day for Active History, as a travel writer for Gapyear.com, and for a short story in the Journal of Australian Indigenous Issues.

\section{ARTICLE CITATION}




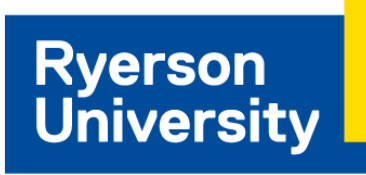

Fashion

Faculty of Communication

\& Design

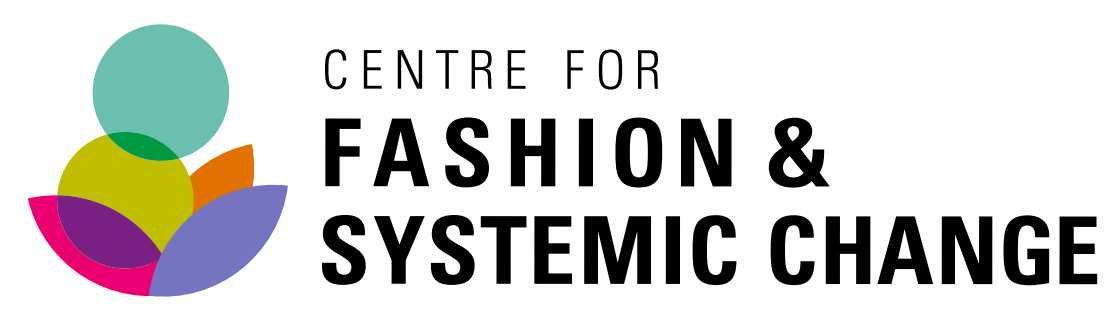

Frows $\mathrm{SH} / \mathrm{ON}$

\section{ISSN 2371-3453}

Copyright (C) 2020 Fashion Studies - All Rights Reserved

Creative Commons Attribution-NonCommercial-NoDerivatives 4.0 International (CC BYNC-ND 4.0) license (see: https://creativecommons.org/licenses/by-nc-nd/4.0/) 